Article

\title{
Into the Grey: The Left, Progressivism, and Christian Rock in Uptown Chicago
}

\author{
Shawn David Young \\ Clayton State University, 2000 Clayton State Boulevard, Morrow, GA 30260, USA; \\ E-Mail: shawnyoung@ clayton.edu; Tel.: +1-678-466-4758
}

Received: 6 April 2012; in revised form: 10 May 2012 / Accepted: 24 May 2012 /

Published: 8 June 2012

\begin{abstract}
Founded in 1972, Jesus People USA (JPUSA) is an evangelical "intentional community" located in Chicago's Uptown neighborhood. Living out of a common purse arrangement, this inner-city commune strives to counter much of what the Right stands for. An expression of the Evangelical Left, the commune's various expressions of social justice are popularized through the music produced by the community and their annual festival.
\end{abstract}

Keywords: evangelicalism; progressivism; progressive Christianity; Christian rock; Jesus Movement; communes; evangelical left

\section{Introduction}

The Reagan era is commonly regarded as a "conservative" time in U.S. history, galvanizing both the political and religious Right to wage a war over what was perceived as lost American values. Despite a marked upsurge in religious and political conservatism (particularly among evangelical Christians) various groups developed, hoping to operate as counterweights to an imbalance created by the Right. Many of these groups emerged out of the "Jesus Movement," a revival of conservative, evangelical Christianity among youth throughout the late 1960s and 1970s. Although most expressions of this movement were eventually co-opted by the Religious Right, one community managed to maintain a separate identity. Jesus People USA (JPUSA) maintains a successful outreach to low-income families and the homeless in Chicago's Uptown neighborhoods. Throughout American history, communal experiments have failed or have been relatively short-lived. However, JPUSA's success, I contend, can be attributed to four things: (1) The complete commitment of communards to a larger cause; (2) A plurality of leadership [1]; (3) A number of community-owned and operated 
businesses; (4) The wide success of the Rez Band (a Christian hard rock group comprised of founding members) and the community's annual Cornerstone Music Festival [2].

Both the music group and the festival have endeared the community to the larger evangelical subculture since 1984. The result has been a newfound respect for (or at least tolerance of) left-wing political positions articulated by fans of the band and the festival. Moreover, the festival serves as a means to inspire other like-minded persons of faith to join in JPUSA's cause. This development is significant, since today's "evangelicalism" is (in many ways) a result of a form of baby boom evangelicalism that emerged during the 1970s [3]. Although progressive Christianity is commonly associated with theological and political "liberalism," it is widely accepted that "progressivism" (as applied to Christianity) is too multifaceted to assume any static representation of the whole - the "totality" of this particular expression of Christianity. Moreover, as merely one expression of progressive Christianity, the emerging Evangelical Left holds ideologies common to both the Right and the Left. Thus, this expression has carved out a different path from mainline liberalism and conservative evangelicalism.

Although the Evangelical Left has charted a different path from the traditional Left and Right, this particular expression of Christianity offers more confirmation that ideological positions are not behemoths in the sense of being immovable or intractable. On the contrary. As with most social movements, evangelicalism is peppered with idiosyncrasies that maintain a broad political and theological continuum. JPUSA complicates our traditional understanding of evangelical Christianity and, more to the point of this paper, exemplifies progressive evangelicalism - and does so to the tune of Christian rock music.

\section{The Jesus Movement}

During the late 1960s there was a revival of conservative, evangelical Christianity among youth in the U.S. While this included youth from a number of backgrounds and traditions, hippie Christians entranced media to the point of making headlines with major publications such as Time and Life. Commonly referred to as the Jesus Movement, the revival challenged traditional Christian aesthetics while embracing a conservative understanding of the Bible. Dubbed "Jesus freaks," hippie converts represented a group of Christians who displayed qualities reminiscent of the Great Awakenings. Donald E. Miller has considered the impact of the Jesus Movement, arguing that it had the makings of a second Reformation: "Many of the principles of the Reformation were reborn as ordinary people discovered the priesthood of all believers, without ever reading Martin Luther" [4]. Similarly, Jesus freaks questioned the authority of the church and reinstated biblical authority, but retained a countercultural aesthetic often sporting the hippie "image" while using popular music for evangelism.

Christian hippies emerged in the midst of what was, perhaps, a perfect storm. Among many things, the late 1960s were marked by student protest movements, the war in Vietnam, race riots, and disenchantment with both the Right and the Left. As many youth sought enlightenment (hoping to quell existential angst) some chose the path of Jesus. Zealous with newfound faith, Jesus freaks emerged, proclaiming the gospel in their own cultural vernacular. Unconventional, non-traditional, long-haired followers of Jesus successfully melded the pop aesthetics of the counterculture with the theological conservatism of evangelical Christianity. This blending of the hippie aesthetic with conservative Christianity became 
emblematic of the Jesus Movement [2]. But this was not exactly groundbreaking, observes Preston Shires, since "countercultural Christianity had its roots in the avante garde of evangelicalism," which involves a lengthy history of evangelicals thoroughly engaged within their respective cultural milieus, including Charles Fuller, Billy Sunday, George Whitefield, and Billy Graham [5].

Billy Graham actually made the Jesus Movement viable when he offered a bridge for countercultural youth to return to evangelical Christianity [6]. For youth, evangelism and outreach surfaced in mediums such as publishing, film, television, festivals, and music, and became a powerful force within American popular culture. This continued the historical lineage of American evangelicalism, affirming what David Bebbington and Nathan Hatch consider a complex, growing movement [7]. But in the midst of the theologically and socially conservative Jesus Movement, a parallel story developed.

\section{Jesus People USA}

Jesus People USA (JPUSA) is an inner-city commune of post-Jesus Movement Jesus freaks located in Uptown Chicago. In many ways, this community is emblematic of the original Jesus Movement. But in other ways they have diverged, charting a path alongside the Evangelical Left. Founded in 1972, JPUSA has continued to grow and thrive due to ideological flexibility and a model of government based on what the commune refers to as a "plurality of leadership" [2]. Their survival can also be attributed to what Rosabeth Moss Kanter calls "commitment mechanisms" [8] that result in continued dedication from communards. Simply put, JPUSA has continued since 1972 as a result of two factors, according to my previous research: collective commitment and individual agency. Moreover, commitment to higher purpose (grounded in models of social justice) allows JPUSA communards to adapt to a series of events that would have otherwise dissolved the group [2].

Inspired by the book of Acts, JPUSA communards have successfully created a unique communal environment, something that is, in many ways, antithetical to establishment forms of evangelicalism commonly associated with political conservatism and laissez-faire capitalism [9]. Housing an average of four hundred members (including old hippies, young punk rockers, and "straights") the group embraces a modest form of socialism; all earnings generated by JPUSA businesses are relinquished and placed in a common purse.

All individual residents of the community are considered part of an extended family, functioning within a larger structure that operates several ministries and businesses throughout Chicago and abroad. The most visible include Lake Front Roofing Supply, Cornerstone Community Outreach (a homeless shelter), Tone Zone (a recording studio), Grrr records (a record label), and an internationally known music festival - an event reminiscent of Woodstock. The Cornerstone Festival is held on the community-owned six hundred acre Cornerstone Farm outside of the rural Bushnell, Illinois. The fact that such a large post-Jesus Movement commune is still around necessitates an analysis of the community and a brief foray into the historical context from which it arose [2]. Timothy Miller refers to JPUSA as "one of the largest single-site communes in the United States" [10].

Although Jesus Movement communes such as JPUSA were founded on the basis of evangelical Christianity, this particular group remains conflicted over their religious identity. While moderately evangelical, the community does not identify with the Religious Right, nor does it fully identify with 
liberalism. Their political affiliation places them outside of what has largely defined mainline evangelicalism since the late 1970s. And yet the group enjoys favor with its parent denomination, the Evangelical Covenant Church (ECC) and various evangelical publications such as Christianity Today [2].

Members of JPUSA are attracted to a life of service and communal living. But given the nature of collective living, what is the attraction? Timothy Miller has observed that while Americans remain unflinchingly individualistic, the communal ethic continues to attract interest. Americans continue to consume books and documentaries that depict communal life. Yet there remains a conflict between communalism and individualism. While the communal ethic continues to fascinate many, popular understandings of communal living tend to be overly reductive, linking collectivist efforts to cultish hippie experiments or obscure nineteenth-century millenarian sects. When considering the reasons for attraction or revulsion to the communal ethic, we must consider the ways in which communes can be appropriately understood. Kanter has observed that contemporary North American communes can be placed into two categories: "retreat" (defined by negative boundaries) and "service" (defined by affirmative boundaries) [11]. The former seeks to retreat from the evils of the world, are peopled by isolationists, and often lack the proper commitment for sustainability. The latter engage society, are mission-minded, operate based on shared values, and often prove more successful than retreat communes.

A twenty-first century example of a service commune, JPUSA's structure is inspired by the writings of Jean Vanier, Catholic founder of L'Arche communities, an outreach that provides a home for disabled persons. Vanier's Community and Growth (1979) has been a seminal document in the community's organizing principles and sustains commitment mechanisms. Their public statement demonstrates commitment to those in need and indicates religious inclusiveness:

L'Arche enables people with and without disabilities to share their lives in communities of faith and friendship. Community members are transformed through relationships of mutuality, respect, and companionship as they live, work, pray, and play together. In these ways, L'Arche USA gives witness to the vision that people of differing intellectual capacity, religion, and culture can come together in unity, faithfulness and reconciliation. While some of our communities were founded in the Roman Catholic Church tradition, today L'Arche USA communities are ecumenical and welcome people of all faiths [12].

While JPUSA draws organizational inspiration from L'Arche, they maintain stricter boundaries of religious distinction. Vanier remarks that "the secret of L'Arche is relationship: meeting people, not through the filters of certitudes, ideologies, idealism or judgments, but heart to heart; listening to people with their pain, their joy, their hope, their history, listening to their heart beats" [13]. JPUSA, however, adopts a modest ecumenism. While theirs is not as far- reaching as L'Arche, they uphold the spirit demonstrated in Vanier's work. Members of JPUSA are drawn to a life of service toward the less fortunate.

\section{Jesus People USA and the Left}

It is not unprecedented for a music group to morph into a politically conscious social voice. Music groups such as the Grateful Dead, the MC5, Public Enemy, and U2 evidence the power wielded by musicians and their followers who, for all intents and purposes, seek social change in a culture viewed as anemic. A group influenced by the music of Jimi Hendrix, Led Zeppelin, Jefferson Airplane, and 
Cream, the Rez Band charted a path now followed by evangelicals who, for the most part, have often identified as conservatives [2]. But the positions held by these fans are not without historical precedent. The New Left of the 1960s established a paradigm that many evangelicals began to adopt throughout the 1970s and 1980s.

Viewing the social reform efforts of the Old Left as flawed, the New Left focused on individuals, taking up what Todd Gitlin refers to as "practical moralisms" [14]. These activists viewed their forerunners as outdated and overly focused on the economics of the proletariat. For them, the American middle-class "seemed impersonal, bureaucratic, and inhumane," according to James J. Farrell. A pacifist, Marxist, and Christian Socialist, Dorothy Day (1898-1980) was a key-figure in American Catholic social justice. Farrell points to the revolutionary publication of both Day and the French peasant intellectual Peter Maurin: "The Catholic Worker decried the assumption of American capitalism (and of American labor) that work could be understood mainly as a commodity rather than as a means of fulfilling people's spiritual and material needs." Maurin considered Pope Pius XI's argument that raw materials leave the factory "ennobled" while workers come out "degraded" [15]. Their teaching offered a model for hospitality houses, Christian communal living, and ethics based on the teachings of Gandhi. Among other social outreach measures, Day founded the Chicago House, which provided shelter for over three hundred individuals nightly [16]. In many ways, the New Left drew inspiration from both Day and Maurin.

Although the Left seemed largely divorced from evangelicalism during the 1960s, many of the forerunners were grounded in the same impulse that would inspire some Jesus Movement communes. Alive and well at the YMCA at the University of Texas, a leftist faction grew. Inspired by the writings of Albert Camus, theologian Paul Tillich, Reinhold Niebuhr, H. Richard Niebuhr, and Martin Luther King, Jr., the SDS (Students for a Democratic Party) sought to alleviate existential anxiety through finding a sense of purpose, hoping to realize what the Old Left could not [17].

Chicago's homeless population benefitted from social philosophies that both the New Left and Catholic Left embraced. The SDS established models for collective activism that were collectivist, but not totalitarian. Rossinow notes that during the formative years of the New Left, the Student Nonviolent Coordinating Committee (SNCC) and the SDS encouraged the concept of a "redemptive community." In the search for authentic examples of humanitarianism and humanness, New Left radicals believed the search for human authenticity occurred "in a communal context" [18]. When the options were considered - the isolationism of a free-market system and the conformity indicative of collectivism - a middle way was considered, one that would alleviate the crisis of meaning by providing a sense of community without totalitarian control.

Although countercultural communes have often been rural, Chicago was one of many urban environments that allowed the politics of the counterculture to emerge. Faced with problems associated with the "depersonalization" of individuals, various youth during the 1960s and 1970s sought to pool their resources, hoping to counter a climate that came to define many parts of American society [19]. Noreen Cornfield considers how during the counterculture, Chicago's communes attracted dedicated adherents to what amounted to ephemeral experiments.

During the 1970s, hundreds of young adults in the Chicago area sought to demonstrate their moral convictions by living in secular, urban communal households. Few of these communes survived after the end 
of the Vietnam War and the decline of the protest movements of the 1960s. Although the communes were temporary, their histories broaden our vision of social possibilities [20].

These "moral convictions" concerned a recapturing of many of the same impulses that defined the New Left. Moreover, the temporality of these communes and the exodus of urban churches (as they retreated to the suburbs) created a space for evangelicals such as JPUSA to experiment with leftist ideas within an evangelical framework. JPUSA has been able to locate a balance between the individual and the community (a middle way); and their location contributes to this clean balance. A rural scenario might have undermined their sense of purpose — one driven by the post-industrial needs of those living in Uptown - as well as their unique balance between individual and community [2].

\section{In The Midst of Reagan-Era Evangelicalism}

Throughout the 1970s and 1980s evangelical activism was, for the most part, confined to a war over family values. The idea of radical evangelical activism (of the leftist variety) was fleeting at best. In the aftermath of decades of inner-city turmoil, JPUSA and Rez Band offered Uptown a combination of radical activism, outreach measures similar to the Catholic Worker model, and the evangelicalism of D.L. Moody. What has made newer forms of social activism necessary was actually the failure of the New Left. Todd Gitlin writes that "The New Left, like its predecessors, failed to create lasting political forms; when SDS was torn apart, so was the chance for continuity." Consequently, "the New Left failed to produce the political leaders one might have expected of a movement so vast," writes Gitlin. "The millennial, all-or-nothing moods of the Sixties," he contends, "proved to be poor training grounds for practical politics" [21]. Similarly, many Jesus freaks of the Seventies were ill prepared to organize sustained efforts toward social justice. Furthermore, post-Jesus Movement evangelicals during the Eighties (many of whom were part of the Jesus-freak exodus from culture) translated activism in service of the Religious Right during the Reagan years [15]. As exemplars of a Christian understanding of social justice-traced to the Catholic worker model and nineteenth-century progressivism-JPUSA occupies an ideologically interstitial space [2].

JPUSA leadership began to view their calling as a firm commitment to those living and surviving in Uptown. Their vision, however, can be traced to other luminaries-but they were not evangelical. Many organizations have ostensibly offered more aid to the homeless than traditional evangelical models. Randall Balmer suggests that during the nineteenth century, those who adopted dispensational premillennialism tended to "withdraw from campaigns of social reform...to devote their full attention to preparations for the Second Coming of Jesus, which entailed cultivating inner-piety and trying to convert others to the faith." Balmer goes on to highlight the exodus of evangelicals from public life and service, stating, "In the face of mounting social ills, evangelicals shifted their attentions from the long term to the short term-because the time was so brief, they believed, until the return of Jesus." Evangelicals such as D. L. Moody viewed the world as wrecked and abandoned social reform for its own sake, focusing instead on "individual regeneration"-salvation of the human soul [22]. In contradistinction to Moody, the quintessential evangelical, JPUSA adopted what one could consider an unabridged version of the gospel, one which included social activism [2].

The community's political antecedents clearly prepared the way for a social consciousness long absent within evangelical circles. Despite their conservative tendency to focus on spiritual salvation, 
JPUSA has chosen to suture their theological holism to an evangelical identity, mostly as a way to articulate a practical response to problems associated with poverty, as well as the apparent disconnect between social justice and post-1980s evangelical culture [2]. Thus JPUSA's activism in Uptown demonstrates a measure of success in political activism-and it is associated with the way the community views policies championed by the political Right. According to one communard, gentrification has been the cause of relocation for a number of homeless persons [2]. Cornerstone magazine provides one example of JPUSA's perception of the housing crisis in Uptown that warranted immediate action:

As "Reaganomics" took hold in the early 1980s, homelessness suddenly became one of Uptown's most noticeable features. Entire families had nowhere to go. The total number of those we provided dinner for grew (to between two hundred and three hundred a day), and the complexion of those eating with us changed as well, from predominantly single men to entire families. The vast government cuts in housing programs also created a tremendous demand for temporary shelter of any kind. It was obvious that housing had become Uptown's most pressing problem, and we were compelled toward finding solutions [23].

Historically, groups such as Hull House [24], JOIN [25] Heart of Uptown, and various denominations rooted in pietistic traditions (such as the Salvation Army) have taken up Chicago's social outreach initiative. But JPUSA's mixture of evangelical spiritualism and leftist activism informed how the commune related to other city activists. Their direct response en-masse to the problem of homelessness in Uptown occurred during the Eighties. One community leader's recollection reinforces Todd Gitlin's 1970 account of Uptown [26], demonstrating how Gitlin's analysis of Uptown is applicable to subsequent years. Jon Trott states that

[b]y the mid-eighties, homelessness had become not only a neighborhood but a national problem. This was glaringly obvious in Uptown, where in the best of times homeless men and women are easily visible, wandering down Wilson or Broadway streets. In the wake of budget cuts, homelessness became epidemic [27].

While JPUSA recognized the need for action, their affiliation with other radical groups came slowly. Trott recalls the sense of urgency that marked Uptown and various events that inspired JPUSA to action:

Between the years of 1970 and 1985, nearly fifteen thousand units of low-income housing vanished in Uptown. Then-radical Todd Gitlin...wrote in 1970 of his group's efforts to stop gentrification in Uptown. He thought they had succeeded in halting the construction of a community college which would have required the leveling of much of Uptown's core low-income housing. Heart of Uptown picked up the fight that Gitlin's group (JOIN) left behind, but by 1980, Truman College was a reality and 1,500 apartments were history [28].

The connection to such groups came later. JPUSA's initial perception of Heart of Uptown created distance between the two groups. But JPUSA was misguided, according Trott:

We believed the worst about Heart of Uptown without once sitting down and talking to them, grappling with their zealous rage at what was happening to Uptown's poor. Perhaps, like many "good" Christians, we tended to equate conservative politics with conservative morals. And we couldn't help but react to Heart's adversarial approach to politics. We also - and this hurts to admit - reacted to their harsh exteriors, their unpolished language and angry tone. But if we had listened, we would have learned [29]. 
JPUSA learned to cooperate with different organizations that held a common goal. Over the years, the social and political climate of Uptown has been the primary reason for JPUSA's willingness to join forces with a variety of activist organizations. Groups such as JOIN and Heart of Uptown responded to a growing crisis, locally and nationally. "Uptown's history" writes Trott, "was not unique. Both in Chicago and elsewhere, the one-sided struggle between the poor and building speculators has gone on for decades. Low-income neighborhoods fell into the hands of landlords who milked poor renters but didn't keep up the buildings" [30].

JPUSA's activism includes events conservative evangelicals might find unsettling. Trott recalls how the commune once engaged in "protesting American arms dealers gathering at O'Hare Airport for an 'Arms Bazaar' where third world nations showed up to buy; peaceful protests outside abortion clinics;... protests against Bush's illegal war in Iraq; counter-demonstrations against the 'God Hates Fags' people (Fred Phelps) [31]; and political involvement with Helen Shiller once aligned with the Black Panthers and SDS" [32]. A progressive alderwomen in Chicago, Shiller has been noted for her activism in the $46^{\text {th }}$ Ward. Votes cast by JPUSA communards were "the difference in her first being elected in 1987" [33]. The commune has also worked with "Organization of the North East, a group made up of every progressive and ethnic group in the Uptown/Rogers Park area," and has remained actively involved in issues concerning housing, jobs, race, class, and gender [2].

The decision to settle in the inner city was simply a response to what the community viewed as unresolved social issues. As the population in the neighborhood became more diverse, and as churches moved to the suburbs, a gap was left—and it needed filling. Groups like JPUSA continue to meet the needs of areas such as Uptown. However, they have publicly adopted a political philosophy that often challenges the sinews of suburban, evangelical Christianity [34,35]. The Evangelical Left is not a new movement. But leaders such as Trott continue to embrace a leftist ethos, arguing that the American pursuit of wealth is destructive to both workers and communities such as the $46^{\text {th }}$ Ward. As we consider the rather historic political struggles associated with Chicago, we can see that the Left's concern for a truly egalitarian "state" is simply unassailable. Todd Gitlin's account of the 1968 Democratic National Convention in Chicago includes an assessment of how the event still had an effect on American culture in 1987 (the year of the book's publication). He writes: "Two decades later, the polarizations etched into the common consciousness that week [August 25-30,1968] are still working their way through American politics" [36]. Gitlin's account reveals an impulse that grew and continues to inspire social activists on the Left.

The trajectory established by the New Left galvanized those who sympathized with both leftist activism and evangelical Christianity. Evangelical author and activist Jim Wallis decided to combine an evangelical theological orientation with a social position commonly associated with the Left. As one who felt the impact of the earlier movement, Wallis was able to enter the evangelical conversation pertaining to social justice with a sense of authenticity. Early in his life, he became disenchanted with how Christianity was presented - a personal belief with little social relevance. After returning to his faith, he resolved, "God is personal, but never private" [37]. In God's Politics, he writes:

The religious and political Right gets the meaning of religion mostly wrong - preferring to focus only on sexual and cultural issues while ignoring the weightier matters of justice. And the secular Left doesn't seem 
to get the meaning and promise of faith for politics at all—mistakenly dismissing spirituality as irrelevant to social change [38].

It is this combination of progressive politics and suspicion for both Right and Left that characterizes JPUSA's position, though like Wallis, the commune most often associates with the Democratic Party. But despite suspicions for both Right and Left, Wallis and JPUSA appear to hold more in common with the historic Left than with contemporary liberalism. "It is precisely because religion takes the problem of evil so seriously," writes Wallis, "that it must always be suspicious of too much concentrated power-politically and economically-either in totalitarian regimes or in huge multinational corporations that now have more wealth and power than many governments." But he remains equally suspicious of religious claims, particularly when "claims of inspiration and success invoke theology and the name of God" [39].

Many in the New Left were not particularly religious. But like Wallis, their lack of faith in institutions led to an increased faith in radical activism. In the case of JPUSA, this extends beyond soup kitchens and shelters. For commune leaders like Jon Trott, it has become necessary to align with leftist forces as a challenge to the Religious Right. During the 2004 presidential election, Christian Coalition's Pat Robertson (The $700 \mathrm{Club}$ ) stated, "I think George Bush is going to win in a walk. I really believe I'm hearing from the Lord it's going to be like a blowout election in 2004. The Lord has just blessed him....It doesn't make any difference what he does, good or bad" [40]. Hoping to offer damage control for statements such as this, Trott works to inform both Christians and non-Christians that there is an alternative to the Religious Right, the Secular Left and mainline, liberal Christianity [2].

It is strikingly odd that a Christian rock band and their followers (who became the commune) would join the public foray into what has become the so-called culture war. But as we have seen, their immediate environment warranted immediate response, one that came to define (or re-define) their evangelical identity. Chicago is, of course, no exception. Problems can be found in any urban setting beset by mass influxes of people. This along with free-market capitalism (unrestrained competition) creates an environment that is multicultural and rife with economic tension, a recipe for what we have seen in Uptown. But haven't evangelicals historically been on the cutting edge of social justice? Considering the landscape of mid-twentieth-century American religion and politics, George Marsden has emphasized the importance of the liberal/conservative divide and clarifies the primary differences — ones which have theological and political implications:

On the liberal side of the divide were those Americans who placed their strongest emphasis on the values of openness, pluralism, diversity, and mutual tolerance of differences. If these Americans were religious, they typically subordinated theology to ethical concerns [emphasis added].

Various resurgent conservatives, on the other hand, tended to talk more of finding ethical absolutes, which reflected long-standing Christian and Jewish teachings concerning the family, sexuality, discipline, and the importance of moral law [41].

This divide was only exacerbated during the advent of organizations such as the Moral Majority and the Christian Coalition. Unwilling to cede ground to any so-called "liberal" agendum for multiculturalism, multinationalism, or religious pluralism, conservatives have continued to nurse a longstanding objection to those who would challenge American exceptionalism. Thus we are left with 
what Randall Balmer argues has been "the Religious Right's shopworn narrative of the supposed Christian origins of the United States and its subsequent lapse into moral decay," a narrative that reinforces a uniquely American form of Christian individualism while decrying any form of collectivism [42]. But for JPUSA, collectivist living is bound to Christian belief.

JPUSA's emphasis on balancing the individual and the community has informed their work ethic in various community-owned and operated businesses. Workers strive for excellence to achieve a greater good (funding for the community and its social outreach programs), and in so doing, find nonmonetary value in the goods produced [2]. When comparing this community to the New Left and, more specifically, the Students for a Democratic Society (SDS), the ways in which products, people, and time are valued can best be understood in the Port Huron Statement, the first manifesto of the SDS, notes James Farrell. Among many things, the document "called for the end of the depersonalization that reduces human beings to the status of things." Furthermore, it called for "human independence" while warning against "egotistic individualism." This imbued a sense of humanism into the SDS [43]. JPUSA's valuation of humanity exceeds the monetary payoff often sought in mainstream society. In fact, Trott consistently argues that American capitalism (as well as the dehumanizing effects of post-industrial society) creates poverty. For JPUSA, the answer is in their leftwing interpretation of the Bible [2].

\section{Progressivism Communicated Through Music}

Christian music during the 1980s reinforced conservative forms of evangelical belief. However, contemporary expressions of evangelicalism often complicate (or at least underplay) what Donald E. Miller argues has been "any claim to a universal epistemology, or theory of knowledge" [44]. Despite iconoclasm (and despite the tattered history of contemporary Christian music), JPUSA's enigmatic Cornerstone Festival has maintained the appeal of being a serious Christian (evangelical) arts festival. Exploring how artists are represented at Cornerstone provides us with insight into JPUSA and the nuanced evolution of "postmodern" forms of evangelicalism. Does the festival (and by association, JPUSA) somehow mirror what is happening within some sectors of evangelical Christianity? If we are to understand this we must, according to cultural theorist Lawrence Grossberg, understand "what [the] referent is" as well as the "status of the referent" [45]. In considering the various positions on postmodern analyses of text, Grossberg recalls one theory - that:

any interpretation...is an articulation, an active insertion of a practice into a set of contextual relations that determines the identity and effects of both the text and the context. Articulation is the continuous deconstruction and reconstruction of contexts. These articulated connections are sometimes fought over, consciously or unconsciously, but in any case, an articulation is always accomplished...and will always have political consequences [46].

More often than not, the meaning(s) of text dilutes the intention of the author to such an extent that one is hard-pressed to locate any true core "identity," resulting in various ahistorical interpretations of movements, expressions, and so on. Still, given our shared understanding of what the general impulses behind evangelicalism are we can, nevertheless, locate JPUSA within this rather broad tradition. Although religious movements are often defined rather glibly, one can still identify traces of what 
remains commonly held to a particular tradition, if that tradition is examined against the backdrop of canonical definitions. We know that JPUSA is "evangelical" from their theological positions, inasmuch as they accept definitions set forth by scholars who have institutionalized our understanding of evangelical Christianity (Balmer 2006; Bebbington 2005; Marsden 2006). And we know they are "progressive" in their forms of social activism. A brief perusal of JPUSA's Ressurection Band (Rez) will demonstrate how the community gestures toward a kind of activism (and belief) that is commonly held as progressive. Over the years Rez has penned a number of socially conscious songs. In "American Dream" (1980), the band examines various inconsistencies in American life:

The holy morning paper

Slaps the steps of dawn

America's doors open

Let's see what's going on

Confusion with our coffee

Fear and frosted flakes

A Shuttle offstage - a change of scene

The exposé of the American dream

Watergate burglars comedy relief

Laugh at ideals surviving our grief's

It's fool's gold for gilded fools

Playing gaily with twisted rules

Hail to the families in their tv rooms

Suicide, genocide, abortion, cartoons

Terrorism, violence, starving refugees

Conscience, crucified, reality recedes

Nuclear tyrants, computerized plan,

Holding hostage everyman [47]

In "Elevator Muzik" (1981) Rez reduces corporate-driven capitalism to mere façade, or what Walter Benjamin and Jean Baudrillard would refer to as "simulacrum," intimating at the possibility that commercial society (while built on "product") attempts to represent and construct identity. Put another way, the various illusions associated with products and the production of human identity become disassociated with how we would commonly define illusions. The illusion thus becomes reality. In this case, fabricated identities (whether through fashion, entertainment, or other means of escape or selfexpression) become truer than one's actual identity. "Elevator Muzik" identifies hegemonic practices associated with the "culture industry," a concept argued by a great number of Marxist cultural critics.

Who needs rock 'n roll

Who needs song savin' your soul

Plastic musik plastic food

Cellophane tunes for that

Synthetic mood

You got your inspiration from a vending machine

It's an audio starvation diet 
Mannequins on a shopping spree

Who cares if you like it

BUY IT !

It's everywhere I go

It programs my soul

It tells me what I need

It takes me the lead-lead-lead

Elevator Muzik

It's a capital idea

Elevator musik

Programmed just for you

Elevating sales at the speed of sound

Controlling your wallet

Coaxing your soul

The corporate big brother

It's an overload

Get off that conveyor

That treadmill of persuasion

Jesus brings the light into every situation [48]

Through songs such as these, Rez questions ideals associated with American exceptionalism and highlights the ways in which people are marginalized within the context of capitalism. Moreover, many groups that have become popular at the Cornerstone Festival consistently articulate political positions commonly associated with progressivism. Take, for example, Over the Rhine's "Nothing Is Innocent," a song some say is an indictment on American foreign policy:

We'd wake the dead

With voices in our head

We've gotten used to ignoring the truth

We close our eyes

And breathe and eat the lies

That tell us we're so much better than you

All the king's men

Will serve scrambled eggs again

When white-washed walls come crashing down

We'll blink and nod

And say, "How odd"

And wonder why old friends don't come around [49]

The Lost Dog's "Bush League" is a clarion call aimed at U.S. policies on war:

I don't know what I think about it 
But I know what I think of you

Well I know I can live without it

And I know what I want to do

I'll pack you a lunch, clear your desk

It's going to be hell to clean your mess

All I know is that you gotta go

I don't know what I think about it

But your bush league days are through

Will you give me a job I doubt it

Here's a bird in the hand for you

Next time you start a storm

You better get you a mess kit, canteen and uniform

Cause we feel like livin' so you've got to go

Your points of light are almost gone

So here's your yellow ribbon-burning song

For Millie and Danny and Saddam and nanny

Babs and Ronnie and Clyde and Bonnie

Clarence and Ollie and the Beave and Wally

And Maggie and Gorby and the new world ordey [sic] [50]

A musical staple at Cornerstone, the Vigilantes of Love (Bill Mallonee) offers consistent critiques of American society, capitalism, and commercialism.

Now when a need is nonexistent you've got to create desire

Eastern Europe is the most likely buyer

They've been dying for it, crying for it ever since the wall

For syringes, porn, designer drugs, orgasms and shopping malls [51].

Mallonee also examines how human suffering and environmental degradation are connected to the unrestricted pursuit of wealth. "Coal Dust Soul” mulls over the trials faced by a coal miner.

There's always one more kid who'll be gambling

but there's really no escaping the curse

when all yer measured by down here are the veins you can clear

and what you can scrape outta the earth

now to steal the earth's possessions

must surely come with a cost

and I know all my friends down here

by the sound of their cough [52].

But can we truly locate JPUSA's position merely based on these lyrics? Rather than deciphering meaning and representation based on encoding (production) and decoding (consumption), we reserve 
final judgment on texts simply by differentiating between "intended or preferred meanings" and "received or effective meanings," arguing "articulation" of a text is what Grossberg refers to as an

ongoing struggle to produce the text by inserting it into a network of "naturalized" relations. Encoding is a continuous force (e.g., producers continue to make statements), and decoding is already active in the efforts to encode. One cannot separate the materiality of a text from its appropriation, nor can one separate structures from practices [53].

Despite this, we are tempted to locate either the intended or received meanings of Christian lyrics. This is what Jacques Derrida refers to as the "tyranny of language." However, discovering what Cornerstone represents (through its performative scenarios) remains necessary. Thus despite the temptation to dismiss attempts to interpret JPUSA's political position as futile in the glaring light of literary deconstruction, we can still approach the matter with a bit of confidence.

While the process of interpreting lyrics, persons, or events may appear futile, Cornerstone can be located within a broader tradition of evangelical expression. However, Derrida and Grossberg sensitize this study to the fact that Cornerstone is already situated within a preexisting reality inspired by the same forces it resists and is a product of innumerable subjectivities. Put another way, those who interpret the Cornerstone Festival do so within the grid of what is commonly understood as "Christian" music. Methods used to determine a song, a band, or the festival's intended meanings are useful only because they are measured against the appellation of contemporary Christian music (CCM) and contemporary, establishment evangelicalism.

While some might remain suspicious of how fans interpret the festival's "intended" meaning(s), in the end the crux of meaning falls to individual struggle and discursive practices. For Grossberg, "[t]he postmodern reduces reality and ideology to a question of affect: whether and how particular ideological elements matter is not determined by their meanings but by how they can be incorporated into particular mattering maps [emphasis added], particular affective structures." However, Grossberg challenges the critics whose postmodernity ends in mere fragmentation and purposeless nihilism. His challenge includes the need for sites of human struggle - even if the struggle is thought to be futile. In this regard, Cornerstone is postmodern (or post-Enlightenment) — and thus "progressive" — as it avoids strict models of totality, both musically and ideologically [54]. I am focusing on Cornerstone as a site where discourse can produce new ideas or reinforce existing ideas. The seminars, for example, often challenge long-held paradigms. This scenario seems more likely, given the context and space in which Cornerstone operates. According to Grossberg:

Opposition may be constituted by living, even momentarily, within alternative practices, structures, and spaces [emphasis added], even though they may take no notice of their relationship to existing systems of power. In fact, when one wins some space within the social formation, it has to be filled with something, presumably something one cares for passionately. The "functionalism" of the identity that is constructed here opens the possibilities of positive empowerment [55].

Many who attend Cornerstone are "empowered" through reaffirmation of belief in the midst of doubt or by entertaining doubt to challenge belief - their own existing paradigm. Thus, while collective agreement often accompanies gatherings (particularly festival worship services), self-analysis is ever-present as those who attend are encouraged to reexamine their own paradigmatic 
assumptions. But the power enjoyed is then transplanted as new ideas replace the old [56]. Consider Pedro the Lion's "Rejoice:"

Wouldn't it be so wonderful

if everything were meaningless?

But everything is so meaningful,

and most everything turns to shit [57].

Pedro the Lion (fronted by David Bazan) has performed at Cornerstone on side-stages and at the festival's largest venue; the Main Stage often attracts scores of church youth groups. Despite Bazan's often-controversial lyrics and stage demeanor, festival goers continue to categorize the music groups and the festival as both "Christian" and "evangelical" by virtue of historical connections and self-referential understandings of what these terms actually mean and imply. And in many cases, many who attend simply self-identity as both evangelical and progressive. Given this, it is possible to interpret the event based on what is commonly understood as "Christian festival" and "evangelical" [2].

While communard Jon Trott laments the ambiguity of liberal Christianity, he remains biblically progressive, explaining his position as an attempt to "remove my own cultural bias, unexamined assumptions (by examining them), and so on" [58]. This view is evident at Cornerstone, where seminars have shifted toward emergent theology [59]. While Trott fully affirms the traditional creeds of "historic" Christianity, along with so-called "emergent Christians" he entertains a "postmodern," multicultural version of faith, stating

My biggest struggle was and in some ways still is the hiddenness of God...living communally, I think we were tapping into elements that evangelicals at that point weren't tapping into...now I think even emergent is getting passé...but obviously the church is undergoing a shaking along with everything else under this new kind of poly-cultural reality that we're all having to embrace, whether we like it or not. I like it [60].

Evidence of this "polycultural reality" can be seen in bands such as The 77s and The Lost Dogs, two of the festivals most noteworthy veteran groups. "Breathe Deep (The Breath of God)" by the Lost Dogs implies a kind of multicultural acceptance of difference:

Politicians, morticians, Philistines, homophobes

Skinheads, Dead heads, tax evaders, street kids

Alcoholics, workaholics, wise guys, dim wits

Blue collars, white collars, war mongers, peace nicks

Suicidals, rock idols, shut-ins, drop outs

Friendless, homeless, penniless and depressed

Presidents, residents, foreigners and aliens

Dissidents, feminists, xenophobes and chauvinists

Evolutionists, creationists, perverts, slumlords

Dead-beats, athletes, Protestants and Catholics

Housewives, neophytes, pro-choice, pro-life

Misogynists, monogamists, philanthropists, blacks and whites

Police, obese, lawyers, and government 
Sex offenders, tax collectors, war vets, rejects

Atheists, Scientists, racists, sadists

Photographers, biographers, artists, pornographers

Gays and lesbians, demagogues and thespians

The disabled, preachers, doctors and teachers

Meat eaters, wife beaters, judges and juries

Long hair, no hair, everybody everywhere!

Breathe deep

Breathe deep the Breath of God

Breathe deep

Breathe deep the Breath of God [61]

Since 1972 the JPUSA commune has evidenced a growing progressivism, though their political position was not public until the founding of the Cornerstone Festival in 1984 [62]. At century's close, Cornerstone seminars became more reflective of the postmodern fascination held by a growing number of evangelicals. This proved positive for JPUSA and Cornerstone, ensuring a continued evangelical orientation (without the restrictive baggage of conservative evangelicalism) as emergent Christianity grew. Trott was not alone in his departure from Enlightenment-based biblical apologetics. But this did not sit well with some. According to Trott, various counter-cult communities and the apologetics community now feel JPUSA has "drifted" [63]. JPUSA's fellow evangelicals have also made this observation. The Phantom Tollbooth publishes a variety of music, books, and movie reviews, as well as various interviews and resource links. The magazine has been involved with the Cornerstone Festival for a number of years. Magazine editors Shari Lloyd and Linda LaFianza maintain that although JPUSA has always been politically democratic, their theology has changed. The assessment offered by this publication is important, in that it also offers more evidence for the progressive trajectory of musicians, often evidenced lyrically in public iterations on the political climate in the U.S.

Before the advent of emergent Christianity, JPUSA bore positions similar to those of an "evangelical Baptist," according to the Tollbooth editors. Loyd and LaFianza have stated that this position was reinforced by JPUSA's choice of lecturers. However, in February of 2010 Loyd and LaFianza stated that "in the last three or four years, there's been a swing into emergent church beliefs and the seminar speakers are more theologically liberal..." But while emergent theology has consistently grown in influence, "nothing too formal was ever announced or stated" [64]. The festival's original slogan was "Cornerstone: Raw Truth." While Trott admits the slogan is a bit "modernistic," he says the phrase captures the festival's core ethos_- "provocateurs," forcing people to "reexamine or examine for the first time your unexamined assumptions" [65].

JPUSA's ideological evolution is part of a larger historical struggle involving Christianity and social activism [2]. Moreover, their changes (resultant reactions to and in concert with pluralism) parallel how those within establishment evangelicalism have wrestled with notions of culture and truth. Given the increased polarization in American politics, it is not surprising that pundits and voters would coalesce around particular interpretations of religion's role in public policy. Moreover, the fact that the democratization of religion in the U.S. is etched in the fabric of culture only reinforces this polarization. Nevertheless, this is what makes the principles associated with the Enlightenment so 
important to the ontological quest. But what will become of evangelicalism in the future? Perhaps the JPUSA commune and their festival offer a microcosmic example of what might be happening on a larger scale.

\section{The Future of "Emergent," Progressive Christianity}

The rapidly changing world of contemporary Christian music evinces a genre that is now becoming obsolete. In many ways this might influence young "independent" voters who have in the recent past contributed significantly to how the "evangelical vote" is understood. Given the rise of young progressive evangelicals, the political landscape has been complicated to the point that locating any core base seems unlikely. Thus the current shifts in evangelical entertainment (and thus political identity) have enormous implications for how religious "voices" will be heard and understood [2].

At its genesis JPUSA was "evangelical," though they were left-leaning philosophically and practically. Indeed, JPUSA was considered evangelical by other co-religionists. Yet as the 1980s came to a close, the commune's ability to deemphasize the importance of eschatology created a significant difference between their community and other Jesus-freak veterans. Moreover, JPUSA's communal ethic and leftism placed the commune outside the parameters putative to establishment evangelicalism [2].

The commune's choice to share all possessions and to live out of a common purse was in keeping with the structure established by the church in the New Testament. But their form of socialism was not in keeping with the established order, with a largely right-leaning evangelicalism, or with a generic understanding of the Protestant work ethic. Rather than engage in what theorists such as Werner Sombart and Max Weber refer to as a "profit-based" economy, the commune has undertaken a subsistence economy. JPUSA's soul-winning efforts became part of a larger, holistic understanding of the Christian gospel as the emerging leadership sought to meet practical needs of Chicago's homeless. Thus the purpose of "business" has not been profit seeking for its own sake, nor work for its own sake (in the Weberian sense) [66]. Rather, JPUSA engages enterprise to sustain the commune for the purpose of offering assistance to Uptown's low-income population. Consequently, the burgeoning commune diverged from their Jesus Movement progenitors who fully embraced premillennial, dispensational eschatology, a position that placed a tremendous emphasis on the doctrine of the Rapture to the exclusion of social justice.

Uptown became JPUSA's mission field, one that established a perennial context for JPUSA communards to realize a sense of purpose, transcending ideologies and leadership structures—which tend to fade. JPUSA's austere commitment mechanisms have served to keep these communards mobilized in service to the homeless in Chicago's $46^{\text {th }}$ Ward, an area tattered by its history and ripe for social activism. Founded in response to massive numbers of dislocated individuals during the 1980s, the commune's shelter program (as it serves a continuous need in Uptown) creates a symbiotic relationship between communards and commune, reinforcing commitment to a larger cause. Faithful members believe their responsibilities are connected to the communal whole. And communards remain aware that their individual levels of commitment carry consequences when considering the larger JPUSA community and Chicago's homeless population.

This intense commitment to social justice has been translated and transferred to the Cornerstone Festival. The event serves to maintain a zeitgeist arguably extinguished in the wake of post-Jesus 
Movement circumstances: the rapid growth of individualism, the compressing of evangelicalism and nationalism into an identifiable whole, and the commercialization of popular evangelical music. Cornerstone provides an alternative to mainstream evangelical festivals, offers an outlet for independent musicians, and plays part in redefining how popular evangelical music is defined and performed. With a record industry now filled with artists whose beginnings can be traced to the evangelical subculture, it is conceivable that Cornerstone has contributed to a remapping of how evangelical music is represented, challenged boundaries established by the gatekeepers of gospel music, and does so to the tune of progressivism [2].

The fact that JPUSA is interstitial - that they remain culturally relevant while cloistered-is relevant to how communal life is understood. More specifically, that JPUSA is service-based rather than retreat-based confirms Kanter's thesis: successful communes must avoid insularity while simultaneously affirming negotiable boundaries. But while boundaries sustained JPUSA since 1972, the negotiability of these boundaries has also contributed to an ever-eroding commitment among younger members. Given this, JPUSA must consider how communards are to interact with the wider evangelical subculture. Is the commune's international festival influencing evangelical Christianity or being influenced by it? Both. Put simply, Social Movement Organizations (SMOs) "not only mediate the effects of the environment but are partially determined by the environment," writes David F. Gordon [67]. Steven Tipton has considered communal experiments that engaged society. Unlike 1960s isolationist communes, groups studied by Tipton were engaged with the broader culture while remaining interstitial. Much like JPUSA, communards analyzed by Tipton often worked among noncommunal persons, though the purpose of these communards was not wholly related to idealized notions of social uplift [68].

JPUSA and the Cornerstone Festival both occupy a different ideological space - one that does not conform to conservative establishment evangelicalism or liberal Christianity. The juxtaposition of the now tired right-left binary offers little when attempting to ultimately "locate" JPUSA within the broad swath of U.S. religious history. Moreover, despite their somewhat interstitial enclave of resistance, JPUSA's goal (as it pertains to culture and ideas) has been to use Cornerstone magazine (before it went out of publication) and the festival as mechanisms to challenge long-held paradigms [2]. In Rapture Ready, journalist Daniel Radosh comes to this conclusion about Cornerstone:

The open-minded, intellectually adventurous spirit of Cornerstone may still be a small force in evangelical culture, but it seems poised to become influential beyond its size. The younger demographic that's drawn here will soon grow into positions of leadership in the church and society [69].

But many within the younger demographic already occupy positions of leadership. Moreover, Cornerstone has been voicing an "open-minded, intellectually adventurous spirit" since its genesis. Still, the festival was unapologetically evangelical and theologically conservative throughout the 1980s and 1990s. But the close of the century solidified Cornerstone's ability to engage in a different manner of inquiry. Radosh's observation may be a bit late. However, his sentiment rings true - though conservative evangelicalism maintains a cultural foothold, many fans of Cornerstone (though by no means all) continue to view rightist forms of Christianity as dubious, controlled by politically-driven demagogues [2].

Evangelical Christian culture and belief have evolved as a result of dialectical process, as well as the influential power of material culture. As products of this culture, JPUSA and Cornerstone have set 
into motion a process, one that inspires musical forms (particularly of the indie brand) largely divorced from gospel music industry gatekeepers. In so doing, they challenge Niebuhr's "Christ Against Culture" approach to social engagement. Mark Allan Powell has accurately commented on evangelicalism's propensity to adopt this model of cultural interaction:

I have found one of the Achilles' heels of American evangelicalism to be its adoption of the "Christ Against Culture" model, which Niebuhr effectively critiques. But it is an unnecessary weakness, born of a defensive posture that evangelicalism should be able to transcend [70].

Powell goes on to explain how curious it is that evangelicals enjoy significant social power while simultaneously complaining "about how marginalized they are within modern society," noting this is quite evident in CCM [71]. He concludes by addressing JPUSA's role in this drama:

My point is, evangelicals perpetuate the "Christ Against Culture" model insofar as it helps them advance their agenda - but ultimately it is very limiting, and a number of evangelicals are beginning to realize this. JPUSA appears to have been born as a Christ Against Culture movement - but through Cornerstone they evolved toward adoption of a more dialogical vision. This could be the future of evangelicalism in America [72].

Clearly both JPUSA and Cornerstone are evidence that newer progressive forms of evangelical form and expression are emerging. Moreover, the social impact extends to evangelical popular music. I have concluded that two forms of evangelically-inspired music have emerged: (1) a form of CCM that is disconnected from the CCM signifier, yet connected to establishment evangelicalism (which is ideologically conservative); (2) a form rendered unrecognizable due to the forces of pluralism. The latter form can be traced to subcultural music groups showcased at the Cornerstone Festival, many of which teeter between a robust commitment to Christian social justice on the one hand and theological affinities associated with evangelicalism on the other. For example, music groups such as Pedro the Lion represent a nebulous form of evangelical Christianity that affirms a moderate exclusivity about Jesus while also remaining skeptical about evangelical expressions that too quickly judge the validity of other truth-claims. Groups like this (and others at Cornerstone) typify a gentler form of evangelical Christianity. Expressing the progressive ethos of the commune and the festival through music groups marketed to the general market, JPUSA's musical progeny extends well beyond Chicago's $46^{\text {th }}$ Ward.

As the Nineties came to a close, establishment paradigms were questioned as Cornerstone seminars continued to entertain postmodern critical theory. Members of JPUSA found that the dialectical approach to knowledge did not lead to certainty, but more questions. JPUSA and members of the Evangelical Left began to avoid the cognitive, Enlightenment-inspired religion of fundamentalism (read conservative evangelicalism). Favoring the contemplative spirit of a postmodern Christianity (as result of the theoretical), emergent Christians and the Evangelical Left embraced a modicum of theological ambiguity while remaining faithful to a modified form of evangelical Christianity. But their progressivism was most palpably expressed in the political arena [2].

Jesus freaks throughout the late 1960s and 1970s also challenged establishment paradigms. Favoring the experientialism of Pentecostals the provocation of hippie Christians was directed at the religion of mainline liberals, whose method of experiencing God was considered stoic and outdated. While similar in many ways, each historical expression can be considered different based on what is being countered. Early Jesus freaks questioned the liberal mainline. JPUSA questions establishment 
evangelicalism [2]. Similar to early Jesus freaks, the Evangelical Left and emergent Christianity emphasize faith over certitude and create an ironic impulse Donald Miller refers to as "postmodern primitivism" [73]. This is not to suggest, however, that JPUSA and others on the Left have entered with fundamentalists into what Miller considers a "precritical worldview." Rather, it is "to disavow the hegemony of the socially constructed 'rational' mind" [74].

Clearly JPUSA has located a middle ground between the mainstream and the fringe while retaining particular fundamentals, philosophies that situate them within the evangelical paradigm. In like manner, the Evangelical Left now negotiates a position that cannot be regarded as liberal, conservative, or evangelical (in the socio-cultural sense). Cultural theorist Lawrence Grossberg attempts to explain how belief is mediated in the midst of postmodernity:

It is only if we begin to recognize the complex relations between affect and ideology that we can make sense of people's emotional life, their desiring life, and their struggles to find the energy to survive, let alone struggle. It is only in the terms of these relations that we can understand people's need and ability to maintain a "faith" in something beyond their immediate existence. Such faith, which is at least part of what is involved in political struggle, depends upon affective investments that are articulated into but not constituted by structures of meaning [75].

JPUSA's postmodernism (controlled as it might be) amounts to an acceptance of the culture as it is. Embracing the mystery of faith, the community's leadership no longer bases Christian belief on evidentiary polemics. In some ways the commune embraces a modified version of pluralism. But they do so while affirming that ultimate (biblical) meaning undergirds their purpose as a community. For Grossberg, the balance between the postmodern crisis and a meaningful life is in locating purpose in the midst of the crisis. "It is not that nothing matters," writes Grossberg, "but that it does not matter what does, as long as something does" [76]. Put another way, what matters is not the point, so long as we find something that matters. For JPUSA, this "something" remains a dedication to the communal life in service to the less fortunate-and this informs their politics. For Jon Trott, the task of the Christian (and the American) is to serve the community. As a progressive, he embraces the idea of "governance as expressing our social contract with one another" [77].

\section{Conclusions}

JPUSA occupies a nebulous, ideological space symptomatic of cultural pluralism. They are best located in a space that combines the culture-engaging impulse of post-Jesus Movement, establishment evangelicalism and the fringe expressions of isolationist Jesus-freak communitarianism. Despite this liminality, JPUSA is able to retain the spirit of the Jesus Movement. In the end, this creates new questions: (1) Given the forces of pluralism, what is the future of evangelical popular music? Despite the growth of emergent Christianity and the Evangelical Left, conservative forms of belief and popular expression remain quite successful. Although conservative forms of evangelical popular culture remain strong, the Cornerstone Festival has served as a counter-weight for evangelical Christian fans who seek alternatives to long-held paradigms. That Cornerstone in many ways contributed to the remapping of CCM is evident. Many music groups that now enjoy success in the general market developed an initial fan-base at the festival. And given the success of "secular" faith-based bands, will groups still 
considered CCM be absorbed into the secular mainstream? It is difficult to determine any lasting effect as a result of Cornerstone's influence. However, that evangelical Christianity and evangelical popular culture are changing in response to pluralism is clear, though the changes are more often a response to the kinds of conservatism found in the Religious Right, rather than an outright rejection of capitalism [2]. (2) Is it accurate to suggest that through Cornerstone, JPUSA has contributed to an upsurge in the Evangelical Left, or at least more interest in emergent Christianity? Many who have attended the festival are traditional evangelicals. Given their exposure to postmodern theory in a social space defined by commonly held belief-systems, the festival has influenced festival-goers and musicians in ways unlike other evangelical gatherings. Moreover, both JPUSA and Cornerstone may prove inconvenient for establishment evangelicals. In short, JPUSA's philosophy simply nuances the categories of "CCM" and "evangelical" and, perhaps, signals the emergence (or continuance?) of new expressions of evangelical Christianity [2].

That the evangelical subculture has been culturally pliable is not surprising. Philip Goff and Alan Heimert have argued that as historians reengage assumptions about the past, the ground shifts as the discipline of religious history continues to "shape and to be shaped by larger social and cultural forces." They go on to state that further study "uncovers today's strange bedfellows, evangelicals and postmodernists, who together have launched a forceful objection to long-standing historical assumptions and paradigms" [78]. Within this new historical context, categories and movements are in some ways compressed into manageable signifiers. In other ways, they are broadened to include as many other categories as possible (to satisfy pluralism), thus losing any cohesive distinctiveness. The evolution of JPUSA underscores how cultural evolution affects the evangelical parent culture. The Religious Right (and associated cultural products) remains influential in the U.S. However, a new generation now questions the Right and chooses to align themselves with emergent and progressive forms of Christianity. In so doing, they signal the coming of new boundaries, new allegiances, new delineations, new definitions, new reformations, and new forms of popular culture. The idea that pluralism has inspired evangelical Christianity to become more progressive may be overplayed, but the sentiment remains strong.

\section{Acknowledgements}

I would like to express my gratitude to Brantley W. Gasaway for inviting me to contribute this article. Thanks to David W. Stowe, Ann Larabee, Amy DeRogatis, Jeff Charnley, Arthur Versluis, Malcolm Magee, Larry Eskridge, Mark Allan Powell, Randall Balmer, Jay R. Howard, Jason Bivens, Jon Pahl, Timothy Miller, and Matthew Grow. Special thanks to the Communal Studies Association for a generous research fellowship. I would like to extend my gratitude to the wonderful folks at Jesus People USA for opening their homes and their hearts to my project. Special thanks to Martha, Wesley, and Camden Young.

\section{References and Notes}

1. R.M. Kanter. Commitment and Community: Communes and Utopias in Sociological Perspective. Cambridge: Harvard University Press, 1972. 
2. S. Young. "Jesus People U.S.A., the Christian Woodstock, and Conflicting Worlds: Political, Theological, and Musical Evolution, 1972-2010.” Doctoral, Michigan State University, East Lansing, MI, USA, 2011.

3. D.E. Miller. Reinventing American Protestantism: Christianity in the New Millennium. 1st ed. Berkeley and Los Angeles: University of California Press, 1999.

4. Miller, 11, 12.

5. P. Shires. Hippies of the Religious Right. Waco: Baylor University Press, 2007, 111.

6. L. Eskridge. "'One Way': Billy Graham, the Jesus Generation, and the Idea of an Evangelical Youth Culture." Church History 67, no. 1 (Mar., 1998): 106.

7. David Bebbington has argued that that the principles of the Enlightenment made the rise of individualistic evangelical Christianity possible. Bebbington's "quadrilateral" (conversion, biblicism, crucicentrism, and activism) crystallizes his conception of both the heritage of the Reformation and the growth of holiness and pietistic movements in eighteenth and nineteenthcentury American society. Bebbington provides a definition from which I can compare others. Mark Noll prefaces his definition of "evangelical" by suggesting a difference between historical definitions and categorical definitions. The "historical" simply refers to the genealogical organic lineage of any group which can be traced back to figures such as Jonathan Edwards, George Whitfield, or John Wesley. He considers the Reformation and Martin Luther's criteria for Christianity, but uses American revivalists as catalysts for what reformed leaders regard as a movement - evangelicalism as popular conservative Protestantism within the American context, later diverging from reformed theology. Evangelicalism is a complex network of bible colleges, publishers and parachurch organizations which hold to common traits. Thus the movement ("ISM") is somewhat nebulous; D.G. Hart and Jon R. Stone argue that evangelicalism is not a true movement. The "categorical" refers to five categories Noll uses to define evangelical belief: scripture (divine authority and foundation for faith and practice), experience of God (emphasis on encounter and heart-assurance), rejection of institutions (priesthood of all believers, personal hermeneutics), flexibility (evangelicals adjust to culture), and discipline (piety, holiness, tenacity). Nathan Hatch positions evangelical Christianity within the American context, arguing that both the revolutionary spirit of early America and the democratic impulse created a form of Christianity which valued free-will (a departure from Calvinism), anti-clerical, and populist hermeneutics. Thus, a rupture between cleric and commoner created a populist pope, each person their own theologian.

8. R.M. Kanter. Commitment and Community: Communes and Utopias in Sociological Perspective. Cambridge: Harvard University Press, 1972.

9. Acts 2: 44-45 and 4:32-37 (King James Version) states: "And all that believed were together, and had all things common. And sold their possessions and goods, and parted them to all men, as every man had need. And the multitude of them that believed were of one heart and of one soul: neither said any of them that ought of the things which he possessed was his own; but they had all things common. And with great power gave the apostles witness of the resurrection of the Lord Jesus: and great grace was upon them all. Neither was there any among them that lacked: for as many as were possessors of lands or houses sold them, and brought the prices of the things that were sold. And laid them down at the apostles' feet: and distribution was made unto every man 
according as he had need. And Joses, who by the apostles was surnamed Barnabas, (which is, being interpreted, The son of consolation,) a Levite, and of the country of Cyprus. Having land, sold it, and brought the money, and laid it at the apostles' feet."

10. T. Miller. The 60s Communes: Hippies and Beyond. Syracuse: Syracuse University Press, 1999, 99.

11. Kanter, p. 174.

12. http://larcheusa.org/who-we-are.html (accessed on 28 March 2010).

13. Ibid.

14. T. Gitlin. The Sixties: Years of Hope, Days of Rage. New York: Bantam Books, 1993, 84.

15. J. Farrell. The Spirit of the Sixties: The Making of Postwar Radicalism. New York: Routledge, 1997, 28.

16. R. Sutton. Communal Utopias and the American Experience: Religious Communities 1732-2000. Westport: Praeger, 2003, 152.

17. See Doug Rossinow. The Politics of Authenticity: Liberalism, Christianity and the New Left in America. New York: Columbia University Press, 1998.

18. Rossinow, 302.

19. See Todd Gitlin and Nanci Hollander, Uptown: Poor Whites in Chicago. New York: Harper \& Row, 1970.

20. N. Cornfield. "The Success of Urban Communes." Journal of Marriage and Family 45, no. 1 (Feb., 1983): 115-26.

21. T. Gitlin. The Sixties: Years of Hope, Days of Rage. New York: Bantam Books, 1993, 436, 437.

22. R. Balmer. Thy Kingdom Come: An Evangelical's Lament: How the Religious Right Distorts the Faith and Threatens America. New York: Basic Books, 2006, 147.

23. J. Trott. "Life's Lessons: A History of Jesus People USA: Part Five: Who is my Neighbor?" Cornerstone 24 (2011): 45.

24. One of Chicago's social and human service agencies founded in 1889 by Jane Addams. See http://www.hullhouse.org/aboutus/history.html (accessed on 21 May 2010).

25. Jobs or Income Now was formed as a community organizing initiative by the Students for a Democratic Society.

26. See Todd Gitlin, and Nanci Hollander. Uptown: Poor Whites in Chicago. New York: Harper \& Row, 1970.

27. J. Trott. "Part 7 Action-Social and Political, I." Life's Little Lessons. http://www/jpusa.org/ lessons 7.html (accessed on 20 May 2010).

28. Ibid.

29. Ibid.

30. Ibid.

31. A controversial Baptist minister who hosts an anti-gay website titled www.godhatesfags.com.

32. Young, 132.

33. Ibid.

34. Young, 129, 130.

35. See Donald E. Miller. Reinventing American Protestantism: Christianity in the New Millennium, 1st ed. Berkeley: University of California Press, 1999. 
36. T. Gitlin. The Sixties: Years of Hope, Days of Rage. rev. New York: Bantam Books, 1993, 326.

37. J. Wallis. God's Politics: Why the Right Gets It Wrong and the Left Doesn't Get It. New York: HarperCollins, 2005, 34.

38. Wallis, 3 .

39. Wallis, 5 .

40. Wallis, xxiii.

41. G. Marsden. Religion and American Culture. Belmont: Wadsworth/Thomson Learning, 1990, 248, 249.

42. Balmer, 105.

43. "Students for a Democratic Society." Port Huron Statement. 15 June 1962. http://history.hanover.edu/courses/excerpts/111hur.html (accessed on 13 January 2011).

44. D. E. Miller. pp. 22, 23.

45. L. Grossberg. "A Prisoner of the Modern?" Culture Machine. http://culturemachine.tees.ac.uk/ Cmach/Backissues/j001/articles/art_gros.html (accessed on 2 June 2010).

46. L. Grossberg. "Putting the Pop Back into Postmodernism." Social Text, no. 21, Universal Abandon? The Politics of Postmodernism. Durham: Duke University Press, 1989, 168, 169.

47. Colours. Light Records, 1980.

48. Mommy Don't Love Daddy Anymore. Light, 1981.

49. Over the Rhine. The Trumpet Child. Great Speckled Dog, 2007.

50. Eugene/Taylor. Scenic Routes. BAI Records, 1992.

51. B. Mallonee. "Songs on the Radio." Jugular, Fingerprint Records, 1990.

52. B. Mallonee. "Coal Dust Soul.” Works (in) Progress Administration. Vol. 8.

53. Grossberg, 169.

54. Grossberg, 181.

55. Grossberg, "Putting the Pop Back into Postmodernism." Social Text, no. 21, Universal Abandon? The Politics of Postmodernism. Durham: Duke University Press, 1989. 169.

56. Young, 210.

57. Control, Jade Tree, 2002.

58. Young, 164.

59. Young, 164, 165.

60. Young, 164.

61. T. Taylor. The Green Room Serenade. Fools of the World, 2012.

62. S. Young. "From Hippies to Jesus Freaks: Christian Radicalism in Chicago's Inner City." Journal of Religion and Popular Culture 22 (2010). www.usask.ca/relst/jrpc/art22\%282\%29jesusfreaks.html.

63. S. Young. 2011, 166.

64. Young, 165.

65. Ibid.

66. M. Weber. The Protestant Ethic and the "Spirit" of Capitalism. New York: Penguin, 2002, 19.

67. D. F. Gordon. "The Role of the Local Social Context in Social Movement Accommodation: A Case Study of Two Jesus People Groups.” Journal for the Scientific Study of Religion 23 (Dec., 1984): 394. 
68. Tipton, Steven M. Getting Saved from the Sixties: The Transformation of Moral Meaning in American Culture. Berkeley: University of California Press, 1982.

69. D. Radosh Rapture Ready: Adventures in the Parallel Universe of Christian Pop Culture. New York: Scribner, 188.

70. Young, 282.

71. Ibid.

72. Young, 283.

73. D. E. Miller. Reinventing American Protestantism: Christianity in the New Millennium, 1st ed. Berkeley and Los Angeles: University of California Press, 1999, 87.

74. Miller, 122.

75. L. Grossberg. Putting the Pop Back into Postmodernism, 179.

76. Grossberg, 180.

77. J. Trott. "Barack Obama's Federal Deficit Speech: One More Reason I Appreciate this President."Blue Christian on a Red Background. 13 April 2011. http://bluechristian.blogspot.com/ 2011/04/barack-obamas-federal-deficit-speech.html (accessed on on 9 May 2012).

78. P. Goff, and A. Heimert. "Revivals and Revolution: Historiographic Turns since Alan Heimert's 'Religion and the American Mind."' Church History 67, (Dec., 1998): 695, 696.

(C) 2012 by the authors; licensee MDPI, Basel, Switzerland. This article is an open access article distributed under the terms and conditions of the Creative Commons Attribution license (http://creativecommons.org/licenses/by/3.0/). 